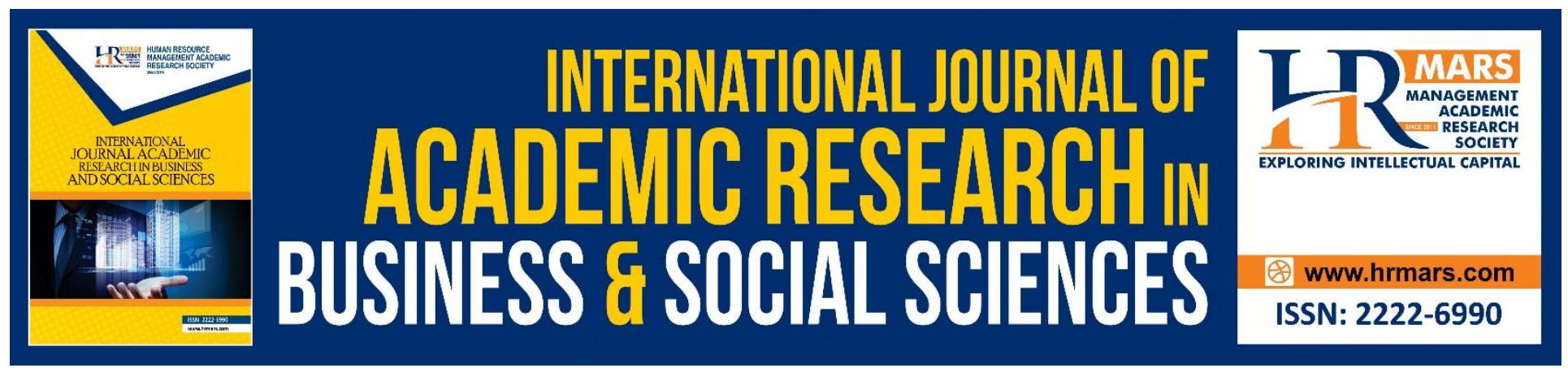

\title{
The Way Forward: Opportunities and Challenges of Sustainable School Disaster Education in Malaysia
}

Vivien How, Ezza Sabrina Azmi, Haliza Abdul Rahman, Khairuddin Othman

To Link this Article: http://dx.doi.org/10.6007/IJARBSS/v10-i15/8252 ～DOI:10.6007/IJARBSS/v10-i15/8252

Received: 12 October 2020, Revised: 10 November 2020, Accepted: 30 November 2020

Published Online: 14 December 2020

In-Text Citation: (How et al., 2020)

To Cite this Article: How, V., Azmi, E. S., Rahman, H. A., \& Othman, K. (2020). The Way Forward: Opportunities and Challenges of Sustainable School Disaster Education in Malaysia. International Journal of Academic Research in Business and Social Sciences, 10(15), 315-324.

\section{Copyright: (c) 2020 The Author(s)}

Published by Human Resource Management Academic Research Society (www.hrmars.com)

This article is published under the Creative Commons Attribution (CC BY 4.0) license. Anyone may reproduce, distribute, translate and create derivative works of this article (for both commercial and non-commercial purposes), subject to full attribution to the original publication and authors. The full terms of this license may be seen

at: http://creativecommons.org/licences/by/4.0/legalcode

Special Issue: Youth and Community Wellbeing: Issues, Challenges and Opportunities for Empowerment V1, 2020, Pg. 315 - 324

http://hrmars.com/index.php/pages/detail/IJARBSS

JOURNAL HOMEPAGE

Full Terms \& Conditions of access and use can be found at http://hrmars.com/index.php/pages/detail/publication-ethics 


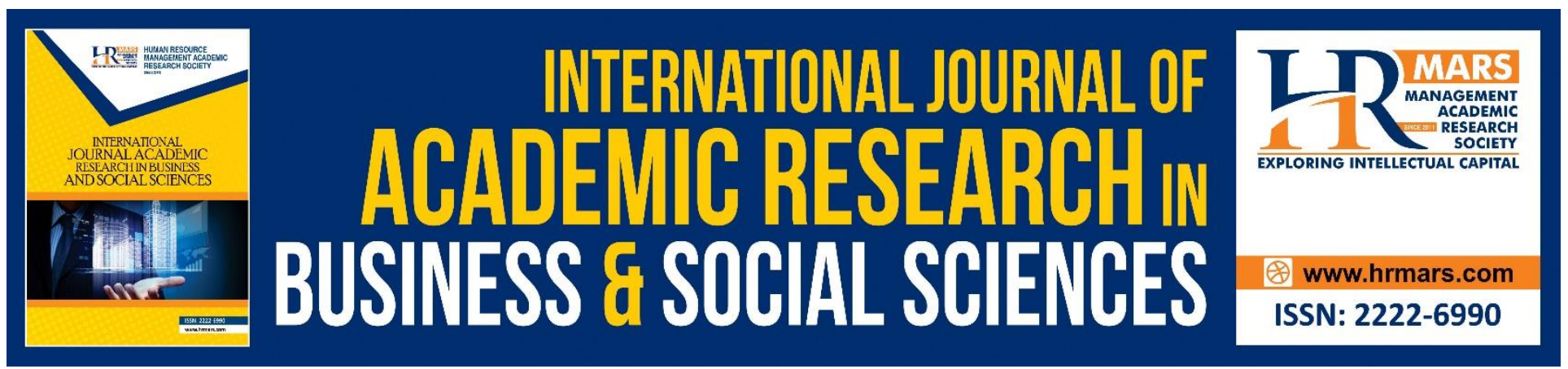

\title{
The Way Forward: Opportunities and Challenges of Sustainable School Disaster Education in Malaysia
}

\author{
Vivien How ${ }^{1,2}$, Ezza Sabrina Azmi², Haliza Abdul Rahman ${ }^{1,2}$, \\ Khairuddin Othman ${ }^{3}$
}

${ }^{1}$ Institute for Social Science Studies, Universiti Putra Malaysia, Selangor, Malaysia, ${ }^{2}$ Department of Environmental and Occupational Health, Faculty of Medicine and Health Sciences, Universiti Putra Malaysia, Malaysia, ${ }^{3}$ Department of Community Support and Services, Malaysian First Aid Society, Selangor, Malaysia

Email: vivien@upm.edu.my

\begin{abstract}
Malaysian government slowly adopted disaster education following the flood disaster in the year 2015 that disrupted the country's healthcare, education, and economic development. Since then, school-based disaster risk education has been widely implemented by the school or through the nongovernmental organization (NGO) providing a one-off or ad-hoc disaster education program. This has seemed as unsustainable as school authorities rarely follow up on learning outcomes and positive changes rarely seen between schools. With the preliminary traditional literature review, this paper aims to conceptualize the school disaster education model by outlining the factors that challenge the implementation of a sustainable school disaster education in Malaysia. Schools are vulnerable to the impact of a disaster, by instilling of disaster education at the school level, their preparedness would help countries improve school children's safety and resilience while limiting the disruption of education in the event of disasters, at the same time, reduce the cost of disaster losses and enhance social cohesion.
\end{abstract}

Keywords: Disaster Risk Reduction, Disaster Education, Sustainable Education, School, Malaysia.

\section{Introduction}

Malaysia's monsoon season likewise affects schools in the country for the past decade. These disaster cause damage to school buildings, loss of furniture, learning materials and equipment, resulting in disruption of the education program. Since "schools are constitutionally responsible to ensure the safety of students under the common law doctrine of in loco parentis" (Tie, 2014), the government has proposed to carry out disaster education via different platforms across the country with the collaboration between stakeholders providing a one-off or ad-hoc disaster education program (Ismail et al., 2016; Sobian, 2016). Although the implementation of disaster education includes government 
sectors, civil society groups, and non-governmental organizations, the success of disaster education at all levels remains far behind (Sobian, 2016). With the preliminary literature review, this paper aims to conceptualize the school disaster education model and outline the contributing factors that challenge the implementation of a sustainable school disaster education in Malaysia.

\section{Literature Review}

This is a preliminary traditional literature review study that aims to outline the challenges and opportunity of disaster education at school in Malaysia. Scopus, ScienceDirect, PubMed and Google search engines were assessed to obtain literature regarding disaster school education in Malaysia. Search strategies included variant terms for "disaster risk reduction", "disaster education", "sustainable education" as keywords.

The Hyogo Framework for Action was the global blueprint for DRR efforts between 2005 - 2015. Its goal was to substantially reduce disaster losses by 2015 - in lives, and in the social, economic and environmental assets of communities and countries via "proactive approach". Global DRR commitment continue with the introduction of Sendai Framework as a 15-year, voluntary, nonbinding agreement that focused on "people centred approach from 2015 - 2030. Since the global DRR commitment initiated since year 2005 and projected into year 2030, the search date range for literature was restricted between year 2010 and January 2020 to examine the outcome of this continuous commitment during this transition of global strategy development.

The inclusion criteria of the articles, reports, and case studies retrieval to be considered in the review were the following: (i) written in English, (ii) open access journal/report/book chapter and documents available on website, (iii) related to either educator or learner in school disaster education in the ASEAN region. The search yielded a total 35 articles that met the inclusion criteria. After eliminating the duplicates and articles which were not related to the review of the abstract; the titles, keywords and abstracts of the articles were then screened for relevance, which left a total of 26 original and review articles suitable for preliminary review in this context. Based on these retrieved information, a Venn diagram of the conceptual model (as shown in Figure 1) was developed by authors in order to summarize the factors that challenges a Sustainable Disaster Education at the School Level in Malaysia. Therefore, this study provide information on the development of disaster education at school level in Malaysia and gives valuable information on the way forward to facilitate communication, coordination and collaboration of the role of different agencies in enhancing disaster education at school levels in the country.

\section{Discussion}

The current disaster education at school level are initiated by school authority, or non-governmental organization (NGO) related to educational bodies. Evidence obtained from handbook reports of governmental agencies or background information of expert committees in the country were gathered to present a convenient summary of Malaysian's commitment in DRR via disaster education. A brief summary of the efforts made by these responsible authorities that impact on the movement of disaster education at school in Malaysia is presented in Table 1. 
INTERNATIONAL JOURNAL OF ACADEMIC RESEARCH IN BUSINESS AND SOCIAL SCIENCES

Vol. 10, No. 15, Youth and Community Wellbeing: Issues, Challenges and Opportunities for Empowerment V1. 2020, E-ISSN: 2222-6990 @ 2020 HRMARS

Table 1: Lesson and Action Taken by Authorized Bodies to Implement Disaster Education in Malaysia

\begin{tabular}{|c|c|c|}
\hline Name of Program /Action & Objective & Authorized Body \\
\hline $\begin{array}{l}\text { The Safe School } \\
\text { Programme (Tie, 2014) }\end{array}$ & $\begin{array}{l}\text { To call for support of families and local } \\
\text { communities in order to reduce school } \\
\text { violence and contribute to a safe school } \\
\text { culture and environment by developing a } \\
\text { blueprint for "Safe School Concept and } \\
\text { Manual: Implementation Guide to Create a } \\
\text { Safe School, Community and Family for } \\
\text { Children" }\end{array}$ & Ministry of Education, Malaysia \\
\hline $\begin{array}{l}\text { ASEAN Safe School } \\
\text { Initiative (ASSI) (Sobian, } \\
\text { 2016) }\end{array}$ & $\begin{array}{l}\text { To improve and accelerate the } \\
\text { implementation of Safe Schools in all ASEAN } \\
\text { Countries by developing regional guidelines } \\
\text { and indicators of safe school. }\end{array}$ & $\begin{array}{l}\text { Ministry Of Education, Malaysia, } \\
\text { National Security Council Of } \\
\text { Malaysia, PLAN International }\end{array}$ \\
\hline $\begin{array}{l}\text { School Preparedness } \\
\text { Programme (SPP) (Ismail } \\
\text { et al., 2016) }\end{array}$ & $\begin{array}{l}\text { To promote a culture of disaster preparedness } \\
\text { and to increase the capacity of schools and } \\
\text { students to respond to disaster }\end{array}$ & $\begin{array}{l}\text { Ministry Of Education, } \\
\text { Malaysia }\end{array}$ \\
\hline $\begin{array}{l}\text { The ASIAN Disaster } \\
\text { Reduction and response } \\
\text { Network (ADRRN) (ASEAN } \\
\text { Safe School Initiative, } \\
\text { 2020) }\end{array}$ & $\begin{array}{l}\text { To strengthen collaboration in disaster } \\
\text { response and risk reduction among the local } \\
\text { civil society in the Asia-Pacific region. }\end{array}$ & MERCY Malaysia \\
\hline $\begin{array}{l}\text { Community-based } \\
\text { Disaster Risk Management } \\
\text { (CBDRM) (School } \\
\text { Preparedness Programme } \\
\text { (SPP), 2020) }\end{array}$ & $\begin{array}{l}\text { To increase the communities' capacity and } \\
\text { resilience by sensitizing stakeholders on } \\
\text { CBDRM concepts and strengthen their } \\
\text { knowledge and skills on disaster preparedness }\end{array}$ & $\begin{array}{l}\text { MERCY Malaysia, Local } \\
\text { communities }\end{array}$ \\
\hline $\begin{array}{l}\text { School Preparedness } \\
\text { Program Training of } \\
\text { Trainers (Embracing the } \\
\text { Winds of Change Annual } \\
\text { report, 2017) }\end{array}$ & $\begin{array}{l}\text { To equip the trainer/facilitator in carrying out } \\
\text { school preparedness modules activities }\end{array}$ & $\begin{array}{l}\text { MERCY Malaysia, Ministry of } \\
\text { Education, Malaysia }\end{array}$ \\
\hline $\begin{array}{l}\text { The ASEAN Knowledge } \\
\text { Sharing Workshop on } \\
\text { Mainstreaming DRR in } \\
\text { Education (Malaysia } \\
\text { Disaster Management } \\
\text { Reference Handbook, } \\
\text { 2016) }\end{array}$ & $\begin{array}{l}\text { To provide platform for capacity building in } \\
\text { mainstreaming DRR in the education sector, } \\
\text { particularly in the school curriculum. }\end{array}$ & $\begin{array}{l}\text { National Security Council Of } \\
\text { Malaysia }\end{array}$ \\
\hline
\end{tabular}


INTERNATIONAL JOURNAL OF ACADEMIC RESEARCH IN BUSINESS AND SOCIAL SCIENCES

Vol. 10, No. 15, Youth and Community Wellbeing: Issues, Challenges and Opportunities for Empowerment V1. 2020, E-ISSN: 2222-6990 @) 2020 HRMARS

It is known that knowledge acquisition and its action implementation in the field are the only effective way to reduce and minimize the disaster impacts. Since year 2010, Malaysian has demonstrated her commitment in upheld the disaster education in school and community level with the collaboration and coordination with different agencies, however, the challenges of disaster education issues that lie underneath that shall be discussed further are what are the factors that either facilitate or hamper the progress of implementation and what are the opportunity shall we consider in this context.

\section{Challenges of Disaster Education at School}

The concept of school-based disaster risk reduction (DRR) education has become increasingly common as a greater emphasis of DRR is placed on the role of schools in reducing risks and building resilience education system (Thi and Shaw, 2016). School-based disaster education is important as it can reach large numbers of people who come together to learn and are essentially teachable (Twigg, 2015). Past studies have shown that disaster education programs can improve children's understanding of risk (Faber et al., 2014; Torani et al., 2019) and enable children to think about the value of disaster preparedness. By doing so, the difference between theoretical knowledge and practical practices of disaster preparedness and response could be bridged (Faber et al., 2014; Bosschaart et al., 2016).

A Safe Schools Initiative flagship program, for instances, was introduced in Malaysia in 2018 that provides hands-on safety preparedness lessons for students and teachers with a basic understanding of disaster risks, including how to plan for and respond in an emergency (Hoffmann and Blecha, 2020). While it intends to reach 1,000 students and 100 teachers in 20 schools across the country, a study suggested that there are gaps in knowledge communication and deficiencies in Malaysia's disaster education, primarily in the following areas.

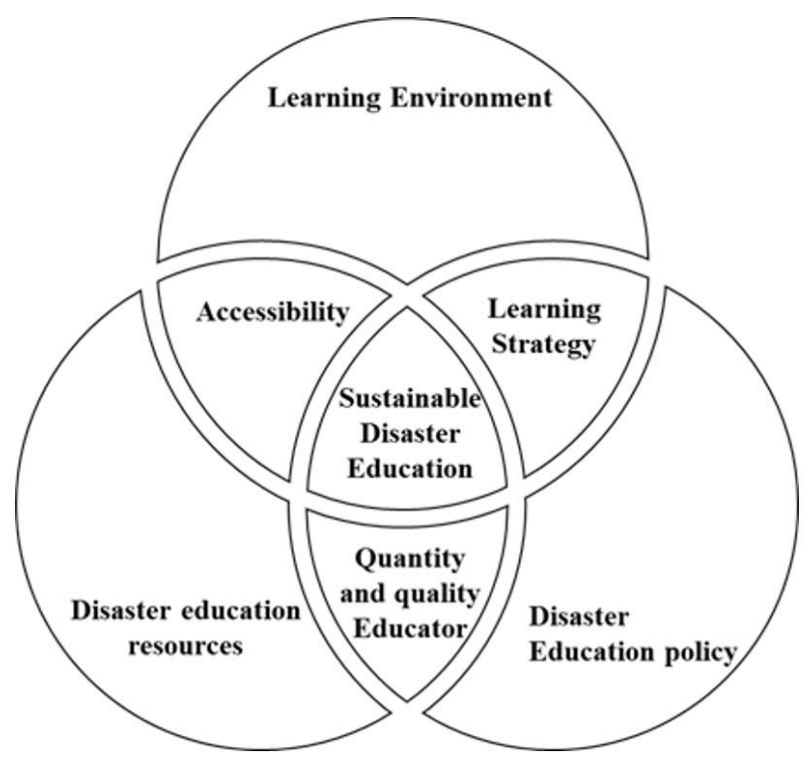

Figure 1: Venn diagram of the Conceptual Model explaining the factors that challenges a Sustainable Disaster Education at the School Level in Malaysia 
- Learning Environment. School site selection, design, construction, and maintenance are the key factors that make the school a safe and resilient learning environment for DRR learning. The fact is that schools in Malaysia have mostly failed to withstand their local hazards and have increased the risk of damage and collapse in the event of a disaster. Schools do not often perform disaster risk assessments and therefore causing both school buildings and school children directly exposed to disaster risk. For example, 636 schools closed for 1 week as the haze worsened in 2019 (Straight time, 2019), 26 schools closed nationwide due to worsening floods (New Straight Time, 2018), and nearly 2,000 children unable to attend school due to floods (The Star, 2019). Also, Ranau earthquake that strikes Sabah in June 2015 was resulting in notable infrastructure damages including schools located near to the epicentre (Singh et al., 2015).

- DRR Policy at School. While death, injury, and lost school days are among the most immediate outcomes of natural and human-made hazard impacts, schools do not pay close attention to disaster management. Instead, school administrative usually concern only with disaster response rather than the holistic disaster management plan (Singh et al., 2015). Our school education system is not used to implement disaster education, therefore, it has not been institutionalized at all levels. In other words, Malaysia's Education System lacks policy and guidance to promote the development of structural hazard-resistant school buildings and non-structural disaster mitigation initiatives. Therefore, they have no adequate measures to identify hazards and assess the disaster risk at the school level to ensure that the sustainable DRR schools initiative implemented at the basis of school structural and non-structural components. Although Malaysia already have the focal agency and organizations that respond to the disaster risk reduction related measures through policy, plan and act (Sarkar et al., 2013) but there is still in need on firm policy and plan in Malaysia that include disaster education as the key component with official policy statement on disaster education in school as priority (Reyes, et al., 2011).

- DRR Learning Strategy. The DRR learning strategy is influenced by both the resilience of the learning environment and the robustness of disaster education policy. Although Malaysia has already taken initiatives in policy and planning towards DRR and resiliency improvement through the existence of the National Security Council (NSC), the policy coordinate and plans activities related to disaster management, which take through different government agencies to run. However, none hardly was seen to include disaster education as the main plan of disaster management activity (Sarkar et al., 2013). The existing disaster learning focused mainly on disaster response and not systematically tailored to map to match all the disaster learning elements into different learning subjects at school. Also, most of the DRR learning outcome is accomplished in a theoretical context with inadequate practical skills to ensure sustainable DRR in all aspects. The fact that the school curriculum is rigid and centrally imposed has increased the difficulty in DRR learning transition without sustained advocacy.

- Disaster Educational Resources and Accessibility. Disaster education is disparity among the school community. This is mainly manifested in two levels: one is the geographical location of urban and rural areas, and the other is the accessibility of the disaster education resources (James and How, 2017). Considering the school site location, such that schools located in coastal areas, 
near to river basin, or distant from the healthcare system does share different levels of disaster risks (Thi and Shaw, 2016). Additionally, there is an imbalance of disaster resilience among schools located in urban and rural areas. The urban area is primarily driven by economic resources, and community resources are the most important driver in rural disaster resilience (Susan et al., 2016). Therefore, the attempt to implement disaster education and enhance resilience in both communities cannot be approached by using a one-size-fits-all education system.

- Quality and Quantity of Educator trained in DRR. Children's role as the major 'medium of change' in disaster education could not be refuted. However, guided empowerment is now seen as another proactive way of empowerment besides the children's empowerment, hence, teachers also play a significant role in this context. Teachers are generally not been trained in disaster education (Mohammad Yusoff et al., 2019). They are not competent to tackle the disaster risk, let alone teaching DRR knowledge, and demonstrate practical skills in school. Malaysia, known as a country with unique geographical conditions consists of a peninsula and northern part of Borneo Island, is always facing a challenging situation in terms of its effort to achieve a similar and high-quality education (Marwan et al., 2014). The remoteness of rural schools and the lack of teachers competent in teaching disaster have also been identified. While various countries have organized different "train-the-trainer" DRR programs to enhance the quality of DRR educators at school, most of it focuses on teaching methods, teaching reform, and strategy. There is very little guidance on matching the teacher's professional background to DRR issues, such as integrated disaster learning at geographic class, art class, language class, etc. School teachers, therefore, rely heavily on the disaster management trainer from outside of school to facilitate the disaster learning session, which is usually a one-off DRR program.

\section{The Opportunity of School Disaster Education in Malaysia}

Disaster education is an important platform for channelling DRR knowledge and developing appropriate behaviour, attitudes, and skills at the school level. To ensure a long term sustainable DRR development, it is crucial to facilitate and develop a DRR culture among the school community, including both school teachers and students. Today's young people must be prepared for unprecedented disasters in a time of climate change for decades to come.

\section{Disaster education contribute to popularizing the disaster knowledge}

Disaster education is one of the effective ways to disseminate disaster information to the general public. Through education a person can obtain essential knowledge, abilities, and skills, and can determine the perception (Hoffmann and Blecha et al., 2020). Through the disaster education process, students would understand and appreciate the facts about the causal mechanism of disaster risks and its interrelation with transdisciplinary sectors. Students will cope effectively with the unexpected future events both physically and mentally, and decreases the trauma as they have been exposed to the essential information needed. By initiating disaster education at the school level, it would help to increase the sense of social responsibility and public awareness among today's youth and guide them to create a disaster resilience in their community. Encouraging behavioural change is very important, but nothing to do overnight. Thus, through disaster education is believe to 
INTERNATIONAL JOURNAL OF ACADEMIC RESEARCH IN BUSINESS AND SOCIAL SCIENCES

Vol. 10, No. 15, Youth and Community Wellbeing: Issues, Challenges and Opportunities for Empowerment V1. 2020, E-ISSN: 2222-6990 @) 2020 HRMARS

promotes disaster knowledge dissemination that contributes to the positive changes in attitude and behaviour of a person and larger community as it should.

\section{Disaster education helps reduce the cost of disaster losses}

Disaster costs continue to rise, and the demand has increased to demonstrate the economic benefit of disaster risk reduction (DRR) to policymakers (Shreve and Kelman, 2014). As disaster occurrences were increasing globally, the significant losses from property damage and livelihood are belief so high that can affect development activities and heighten the community vulnerability (Sarkar et al., 2013). Disaster education is the result of "preventing disasters before they happen", and it aims to enhance one's capacity to adapt and recover from disaster, shocks, or stresses without compromising longterm development prospects. Disaster education would improve the cognitive ability of students and their capability to deal with disasters by minimizing the loss from the disaster and reduce or avoid the occurrence of secondary disasters after the disaster. Effective disaster education will greatly improve the ability of the public to self-help in disaster and minimize the negative mental effects of panic and fear. In the event of a disaster, this will significantly enhance the national disaster relief mechanism and thus reduce the costs of disaster relief and increase the success rate of the disaster relief and recover before back to normalcy.

\section{Disaster education can enhance social cohesion}

The development of disaster education would be part of the functions and responsibilities of social development. At the national level, the role of disaster education in the promotion of social cohesion, economic growth, and research and development should not be neglected. At the individual level, education helps to develop the skills, attitudes, and behaviours needed to lead a healthy, productive, and meaningful life. Therefore, if the government integrate disasters learning into the national education system, it will not only improve national disaster awareness and response capabilities, but also support social cohesion, increase community's self-confidence, and recognize the effectiveness of disaster management by the government. Creating responsibility in an individual to well contribute in the community could be achieved via curriculum enhancement in education. Quality education helps a person to develop the values of 'learning to live together' that include the sense of respect and responsibility in the wider community. In this context, disaster education introduces the core values of safety and security measures that are essential contributions to the preparedness and disaster mitigation (Jennifer et al., 2015).

\section{Conclusion}

Making schools the focal point in DRR education for the entire community is a proven effective approach. In order to achieve a sustainable disaster education at the school level, three key components should be considered: (i) the learning environment, (ii) disaster education policy, and (iii) resources for disaster education. Besides, a strategized learning strategy would be influenced by the safe and conducive learning environment and the robustness of disaster education policy. The quality of disaster educators at school would be greatly affected by the robustness of this disaster education policy and readiness of disaster education resources. The resources, infrastructure, and learning environment decide student's accessibility to disaster education. 
INTERNATIONAL JOURNAL OF ACADEMIC RESEARCH IN BUSINESS AND SOCIAL SCIENCES

Vol. 10, No. 15, Youth and Community Wellbeing: Issues, Challenges and Opportunities for Empowerment V1. 2020, E-ISSN: 2222-6990 @) 2020 HRMARS

Educating the public about disasters is the first thing the country must do to prevent disasters. Most of the countries and international organizations have stressed the importance of disaster education, not only on the effort to institutionalize or normalize disaster education but also to improve the social system on a long-term basis. We can then be assured that children receiving disaster education will be able to live up their confidence and bring their awareness, skills, and attitudes into action for early disaster prevention as they become engaged citizens who continue to spread this information to the next generation.

\section{References}

Bosschaart, A., Schee, J. V., Kuiper, W., \& Schoonenboom, J. (2016). Evaluating a flood-risk education program in the Netherlands. Studies in Educational Evaluation, 50: 53-61.

Embracing the Winds of Change. (2017). 2017 Annual Report, MERCY Malaysia. Available online at https://www.mercy.org.my/wp-content/uploads/2015/04/MERCY-ANNUAL-REPORT-2013.pdf. Retrieved 10 May 2020.

Faber, M. H., Giuliani, L., Revez, A., Jayasena, S., Sparf, J., \& Mendez, J. M. (2014). Interdisciplinary approach to disaster resilience education and research. Procedia Economics and Finance, 18: 601-9.

Hoffmann, R., \& Blecha, D. (2020). Education and Disaster Vulnerability in Southeast Asia: Evidence and Policy Implications. Sustainability, 12(4): 1401.

Ismail, K., Shukri, M. F., Badzis, M., \& Abdallah, S. (2016) The Prospect of Implementing Safety Education in Malaysian Primary Schools: from the Perspective of School Administrators. European Journal of Social Sciences Education and Research, 3(2): 45-67.

James, V., \& How, V. (2017). Urban and Rural Inequality in Knowledge, Attitude and Practices on Haze Pollution Episode in Klang Valley, Malaysia. Malaysian Journal of Public Health Medicine, Special Volume (1): 157-162.

Jennifer, B., Amapola, A., Margaret, S., Lynne, B., \& Jean, B. (2015). Overview: curriculum enhancement to promote safety, resilience, and social cohesion. Paris, France: UNESCO International Institute for Educational Planning.

Malaysia Disaster Management Reference Handbook. (2016). Center for Excellence in Disaster Management and Humanitarian Assistance, Hawaii. Available online at https://reliefweb.int/sites/reliefweb.int/files/resources/disaster-mgmt-ref-hdbkMalaysia.pdf.pdf. Retrieved 10 May 2020.

Marwan, A., Sumintono, B., \& Mislan, N. (2014). Revitalizing Rural Schools: A Challenge for Malaysia. Educational Issues, Research and policies (171-188). RMC - UTM Press, Skudai, Johor Bahru.

Yusoff, M. N., How, V., Azmi, E. S., \& Othman, K. (2019). The Educator's perspective: Knowledge, Attitude and Practice on Occupational Safety and Health at School among Primary and Secondary School Teachers. Malaysian Journal of Public Health Medicine, 19(1): 172-178.

New Straight Times. (2018). Available online at https://www.nst.com.my/news/nation/2018/01/320938/26-schools-nationwide-closed-dueworsening-floods. Retrieved 10 May 2020.

Reyes, M. L., Diopenes, V. E., Co, R., \& Berse, P. (2011). Disaster Resilience Starts with the Young: Mainstreaming Disaster Risk Reduction in the School Curriculum. ASEAN Knowledge Sharing 
Workshop on Mainstreaming Disaster Risk Reduction in Education. Malacca, Malaysia: ASEANUNISDR Technical Cooperation.

Sarkar, M. S. K., Begum, R. A., Pereira, J. J., \& Jaafar, A. H. (2013). Addressing disaster risk reduction in Malaysia: Mechanisms and responds. In 2nd International Conference on Environment, Agriculture and Food Sciences: 81-85.

Shreve, C. M., \& Kelman, L. (2014). Does mitigation save? Reviewing cost-benefit analyses of disaster risk reduction. International Journal of Disaster Risk Reduction, 10 (Part A): 213-235.

Singh, S. S. B., Rathakrishnan, B., \& Rabe, Z. (2019). The Perception of Primary School Students about the Earthquake in Sabah Malaysia. 10th International Conference on Education and Education Psychology, Spain, (October 2019). United Kingdom: Future Academy.

Singh, H., \& Subramanian, S. (2015). Health Emergency and Disaster Preparedness in Malaysia. Southeast Asian Journal Tropical Medicine and Public Health, 40(1): 11-15.

Sobian, A. (2016) An Overview of the Participation of Community and Faith-Based Organisations (FBO) in Disaster Preparedness in Malaysia. TAFHIM: IKIM Journal of Islam and the Contemporary World, 9: 87-111.

Straight Time. (2019). Available online at https://www.straitstimes.com/asia/se-asia/636-schoolsclosed-in-malaysia-as-haze-worsens. Retrieved 10 May 2020.

Susan, L. C., Kevin, D. A., \& Emrich, T. E. (2016). Urban-Rural Differences in Disaster Resilience. Annals of the American Association of Geographers, 106(6): 1236-1252.

Tie, F. H. (2014) Strategic tripartite alliance in establishing a safe school programme in Malaysia. School safety and security - lessons in danger (pp.118-125). United States of America: OECD Publishing

Thi, T., \& Shaw, R. (2016) School-based Disaster Risk Reduction Education in primary schools in Da Nang City, Central Vietnam. Journal of Environmental Hazards, 15(4): 356-373.

The Star. (2019). Available online at https://www.thestar.com.my/news/nation/2019/01/28/almost2000-children-unable-to-go-to-school-due-to-floods. Retrieved 10 May 2020.

Torani, S., Majd, P. M., Maroufi, S. S., Dowlati, M., \& Sheikhi, R. A. (2019). The importance of education on disasters and emergencies: A review article. Journal of Education and Health Promotion, 8(85).

Twigg, J. (2015). Disaster Risk Reduction. Humanitarian Policy Group: Overseas Development Institute. 